Cletus C. Coughlin

Cletus C. Coughlin is a senior economist at the Federal Reserve Bank of St. Louis. Thomas A. Pollmann provided research assistance.

\title{
The Competitive Nature of State Spending on the Promotion of Manufacturing Exports
}

T

HE expansion of jobs and incomes is a leading priority of state governments. An increasingly popular view is that economic growth can be stimulated by increasing the amount of manufactured goods that are sold by firms in a state to consumers and producers in foreign countries. To accomplish this, many states have devoted more resources to the promotion of manufactured exports abroad. Very little, however, is known about the effects of this economic development effort.

Research by Coughlin and Cartwright (1987) found a positive relationship between a state's exports and its promotional expenditures. A related issue, the focus of this study, is whether a state's exports are affected by the promotional expenditures of other states.' Are the effects of a state's promotional efforts being counteracted by the expenditures of other states? On the other hand, are the promotional expenditures of other states increasing export demand overall, thereby increasing a state's exports?

This paper begins with an overview of state export promotion expenditures and programs. The subsequent analysis consists of developing and estimating a model of state-manufactured exports for $\mathbf{1 9 8 0}$ that includes standard international trade variables as well as export promotion expenditures. ${ }^{2}$ A summary of the primary results com ${ }^{-}$ pletes the study.

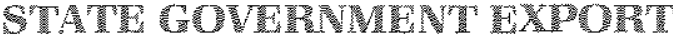 PrOMOTION}

Manufactured exports are an important source of jobs for many state economies. In 1984, the most recent year of estimates in the Annual Survey of Manufactures, more than 500,000 jobs in Califor-

witz's assertion about the effects on Michigan of attracting a parts supplier to Kentucky, the motivation of the Kentucky congressmen is clear. Their goal is to stimulate economic activity in Kentucky with, at most, minimal regard for its consequences elsewhere.

2While some of the data in this study are available for more recent years than 1980, the more recent data are not as complete. For example, more states supplied figures for export promotion in 1980 than in recent years. A second reason for using 1980 is a desire to compare the current results using the export equation with previous research. 
nia, 5.5 percent of private-sector employment, were due to manufactured exports. Though California led the nation in the number of jobs involved, numerous states were relatively move dependent on mamufactured exports for jobs. The percentage of private-sector employment due to manufactured exports exceeded 7 percent for Connecticut and 6 percent for Indiana, Massachusetts, Michigan, Ohio and Washington."

Not surprisingly, states have tried to increase their manufactured exports." State governments provide resources for trade missions and catalog shows. Many maintain overseas offices to provide basic information to potential foreign customers about goods and services available from state firms. The information available through some state govemments (for example, New York) has been expanded by the development of computerized information systems conceming trade opportumities. Some state governments (for example, Illinois and Arkansas) are also becoming increasingly involved in providing financial assistance to exporters. Finally, a number of states are ether developing theit own export trading companies (for example, New York/ New Jersey and Virginia) or assisting private firms using export lrading companies. Due to the alleged cost disadvantages faced by small firms, these state services tend to be geared to small rather than large businesses.

Before 1980, evidence on state export promotional expenditures is scarce. Albatm (1968) a ported sketchy budge information on 36 states 16 of which had no specific budget for 1967. The most complete budgetary data for all states was compiled by Berry and Mussen (1980), who reported state export promotion expenditures of approximately $\$ 18.9$ million during 1980 . These expenditures rellected an average state expenditure of $\$ 377,111$.

Due to the complexity of allocating state budget expendiures to export promotion, these figures are likely to represent a lower bound. For example. although the figures include the salaries of personnel explicitly tied to expon promotion, the salaries of state government officials such as governoms who spend much time and effort promoting exports are not included in these figures. One might also include the salaries of persomel at state universities involved in export promotion as well as the costs associated with providing financial assistance to exporters. Given the small size of the reported state expenditures, these omissions could be relatively important,

Table 1 presents the state export promotion data used in this analysis. Export promotion, which is a very small share of a state's total expenditures, ranged from zero for Utah to more than $\$ 1.8$ million for Ohio. llinois, Virginia and Maryland joined ohio in spending more than $\$ 1$ milition to promote exports.

To take into account the differences among states in terms of their populations, the export promotion figures in table 1 are also presented on a per capita basis. The median expenditure is slighty in excess of 5 cents. On a per capita basis, Alaska is far and away the leading state. Alaska's expenditure of 93 cents pet restdent is more than $21 / 2$ times the per capita expenditure of Montana, the second-leading state. Although neither Alaska (13) nor Montana (18) were among the leading states on a total expenditures basis, those that were, were also among the leading states on a per capita basis. Ohio, Illnois, Virginia and Maryland were ranked 6, 12,4 and 3, respectively, on a per capita basis.

The limited evidence, which mixes expenditures to attract foreign direct imvestment with export promotion, suggests that export promotion expenditures are increasing rapidly. Berry and Mussen (1980) reported that average state expenditures for the promotion of international business increased by a factor of four between 1976 and 1980 for $^{*}$ a sample of 25 states that supplied adequate dala. Figumes from the National Association of State Development Agencies (1986) indicate that such expenditures increased by two-thirds between 1984 and 1986.

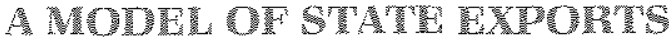

In this section, a model of state exports is presented and estimated. The model incorporates the standard variables used in international trade studies along with export promotion variables. The empirical results shed some light on the effect of a state's promotional expenditures on its ex-

BBetween 1980 and 1984, the relative importance of manufaclured exports for jobs declined; however, recent increases in U.S. exports suggest that this decline has been reversed.

"Barovick (1984) and Ouida (1984) can be consulted for details about the proliteration of export activities. 
Table 1

1980 State Export Promotion Expenditures

\begin{tabular}{|c|c|c|c|c|}
\hline \multirow[b]{2}{*}{ State } & \multicolumn{2}{|c|}{ rotal } & \multicolumn{2}{|c|}{ Percapula } \\
\hline & $\begin{array}{l}\text { Export } \\
\text { Promolion }\end{array}$ & 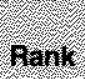 & Exportion & Rank \\
\hline Alobana & 5279750 & 19 & 80109 & 22 \\
\hline Maska. & 372500 & 18 & .9800 & 1 \\
\hline 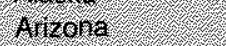 & 407.00 & 32 & 1065 & 34 \\
\hline Altanstac & 175,000 & 27 & 1978 & 20 \\
\hline Caiforina & 2344.24 & 23 & 0100 & 45 \\
\hline golorolo & 120,170 & 80 & 0417 & 83 \\
\hline Corneotucut & 75,000 & 37. & 10242 & 68 \\
\hline trebuare. & 80,000 & 43 & 0504 & 27 \\
\hline Frovera & 450,280 & 12 & 09478 & 29 \\
\hline Ceorgle & 300,50 & 17 & 0575 & 24 \\
\hline ftavbil & 107,250 & 34 & 1112 & 14 \\
\hline 16. & 4.4500 & 40 & 0048 & 49 \\
\hline 1111615 & 1527.060 & 2 & 1649 & 12 \\
\hline holana & 752042 & 8 & 1879 & 11 \\
\hline $16 v_{0}$ & 240273 & 22 & 0826 & 16 \\
\hline Kansas & 70,000 & 186,59 & 0297 & 8 \\
\hline tention & 576010 & 10 & 1584 & 2 \\
\hline dousharhe & 25000 & 44 & 0060 & 48 \\
\hline None & 90,740 & 35 & 0867 & 19 \\
\hline 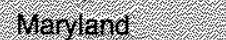 & $1,287,616$ & d. & $50 \%$ & 8 \\
\hline Natssiolusedr & 45000 & 4 & 61078 & 86 \\
\hline hohuger & 6820100 & 9 & 9196 & 21 \\
\hline Ninnosora & 188.000 & 26 & 0462 & 36. \\
\hline NISsissingr & 150,000 & 28 & 0598 & 29 \\
\hline Missourn & 720,000 & 8 & 1467 & 9 \\
\hline Wortand & 277630 & 18 & 3842 & 8 \\
\hline Netraska & 19571 & 24 & 1251 & 18 \\
\hline Nerada & 5000 & 49 & 0068 & 47 \\
\hline Nen I lanipsinie & 20,000 & 45 & 0218 & 40 \\
\hline Mow rersey & 315000 & 16 & 0429 & OI \\
\hline$x+x+10 x=0$ & 70.000 & 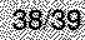 & 00542 & 25 \\
\hline Kew yor & 845000 & 8 & 1046 & 28 \\
\hline Noin Carolna & 503,500 & 4 & 10861 & 16 \\
\hline 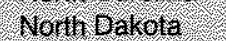 & 89600 & 34 & 1538 & 8 \\
\hline mavo & 1832800 & (2.) & 1704 & 6 \\
\hline Oluahond & 247604 & 21 & 0828 & 17 \\
\hline Oreg6n & 361,767 & 14 & 1362 & 10 \\
\hline Peditsylaria & 203285 & 20 & 0223 & 30 \\
\hline Mhodelshori & 21.250 & 47 & 10120 & 48 \\
\hline Soun Carolina & 100,006 & 30 & 00326 & 35 \\
\hline Sount Dakota & 139.200 & 29 & 2024 & 5 \\
\hline Tennessee & 198,644 & 25 & 0427 & 32 \\
\hline Texas & 739,794 & 6 & 0523 & 26 \\
\hline Uah & 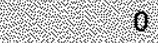 & 80 & 0000 & 50 \\
\hline Homorn & 6.025 & 48 & 10133 & 43 \\
\hline Vugina & $1487,18 \%$ & 3 & 2795 & 4 \\
\hline Washinglon & 333,000 & 15 & 10810 & 18 \\
\hline West virghia & 05773 & 42 & 0186 & 41 \\
\hline Wscons & 82500 & 36 & 0176 & 42 \\
\hline Wroning. & 15,000 & 46 & 0320 & 86 \\
\hline
\end{tabular}

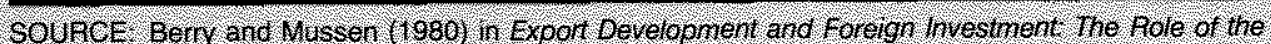
States ond is Inkage to rederal Action. 
ports as well as the effect of export promotion by other states on a selected state.

The Heckscher-ohlin approach to international trade, developed by two Swedish economists, Eli Heckscher and Bertil Ohlin, highlights the importance of a country's productive resources in determining its pattern of international trade. ${ }^{5}$ Goods are traded internationally because of differences in production costs. These differences depend on the proportions in which factors of production exist in different countries (that is, the relative factor endowments) and how the factors are used in producing different goods (that is, the relative factor intensities).

An example can be used to illustrate the Heckscher-Ohlin theory. Assume two countries, the United States and Mexico, two factors of production, capital and labor, and two goods, air planes and cloth. In a two-factor world, a country is capital-abundant labor-abundant) if it is endowed with a higher (lower) ratio of capital to labor than the other country. Assume the United States is capital-abundant and Mexico is laborabundant. In a two-good world, a product is capital-intensive if its production requines a relatively higher ratio of capital to labor than the other good. Assume airplanes are capital-intensive and cloth is labor-intensive. The Heckscher-Ohlin theory predicts that a country will export the good that uses its abundant factor intensively and immport the other good. The reason for this trade pattern hinges on the relative production costs. A country should be able to produce the good that uses relatively larger amounts of its abundant resource at a lower cost. Thus, the United States should export airplanes to Mexico and import cloth from Mexico.

The Heckscher-Ohlin approach allows for pre dictions about trade patterns based on knowledge of countries' factor supplies. Since the services of factors of production are embodied in exports and imports, international trade may be viewed as the

${ }^{5}$ Additional details on the Heckscher-Onlin theory can be found in Krugman and Obsifeld (1988) or any other introductory international trade text.

Uniess noted otherwise, the data were taken from various issues of the Annual Survey of Manufactures.

The bulk of cross-indusiry studies have found physical capital to be a scarce factor (Baldwin, 1971; Branson and Junz, 197t; Sailors, Thomas and Luciani, 1977; Stern and Maskus, 1981): however, the deficiencies of these studies have been highlighted by Leamer and Bowen's (1981) demonstration that inferences about factor abundance were not strictly justified and by Aw's (1983) identification of the highly restrictive conditions that are necessary to justify the inferences. Research by exchange of the services of the country's abundant factor for the services of the country's scarce factor. In the example, the United States exports the services of its abundant factor, capital, and imports the services of its scarce factor, labor. A common summary statement is that capital is a source of comparative advantage for the United States, while labor is a source of comparative disadvantage.

The preceding idea can be applied to regions within a country. In Coughlin and Fabel (forthcomingl, a Heckscher-Ohlin approach was developed to examine the export performance of individual states. The intemational exports of a state (EX) are defined as the value of manufactured direct exports for $1980 .^{.6}$ A state's endowment of manufacturing resources determines its intemational competitiveness. Relying upon a standard Heckscher-Ohlin framework, a three-factor mode with physical capital (K), human capital ( $\mathrm{H}$ ) and labor (L) is used. Thus, a state's exports are related to its relative endowment of these manufacturing resources. A state with langer amounts that are sources of U.S. comparative advantage (disadvantage) will have more (less) exports.

Whether physical capital is a source of U.S. comparative advantage has been a controversial topic since Leontief's (1954) surprising finding that the U.S. exported labor-intensive rather than capital intensive goods. This continuing controversy is irrelevant for the current research. ${ }^{7}$ To reflect the controversy, the expected impact of physical capital, measured by the gross book value of a state's depreciable manufacturing assets, is uncertain.

Stern and Maskus (1981), as well as many others, have concluded that human capital is a source of U.S. comparative advantage. Thus, increases in a state's endowment of human capital, ceteris paribus, are expected to be related positively to state export performance. The calculation of a state's endowment of human capital, following Hufbauer (1970), attributes the difference between a state's

Bowen (1983) and by Coughlin and Fabel (forthcoming), which were designed to avoid the criticisms of cross-indusiry studies, suggests that physical capital is a source of U.S. comparative advantage.

${ }^{8}$ The use of the gross book value of depreciable assets as a measure of physical capital is not ideal. As Browne et al. (1980) have indicated, this measure is derived from accounting practices rather than economics. Consequently, it might not be a good measure of productive capacity. This problem is partially mitigated by the cross-section nature of the current analysis because relative productive capacity rather than absolute capacity is of primary importance. 
average annual pay in manufacturing and the median pay of persons with zero to eight years of education as a return to human capital. This return is multiplied by the number of manufacturing employees to generate a measure of total returns to human capital in manufacturing. A state's endowment of human capital is the capitalized lat 10 percent value of these total retums.

A standard research finding reconfirmed recently by Stern and Maskus (1981) is that labos; measured as the number of manufacturing employees in a state, is a relatively scarce factor in the United States. If this factor is a source of U.S. comparative disadvantage, then increases in a state's endowment of labor, holding physical and human capital constant, should be related negatively to the state's exports.

In addition to a state's endowment of physical capital, human capital and labor, export promotion expenditures are expected to affect manutacturing exports from a state positively. The expont promotion figures cited in table 1 encompass expenditures for the promotion of manufactured on manufactured exports, the use of total export promotion expenditures might introduce some error into the estimations. Unfortunately, the magnitude of agricultural export promotion at the state level is unknown.

Berry and Mussen (1980) reported that the Department of Agriculture in 26 states received funds for export promotion. Since agricultural exports could be promoted by other administrative units, agricultural export promotion is not necessarily restricted to these states. To approximate total expenditures for manufacturing export promotion, total export promotion expenditures were multiand agricultural goods. Since this study focuses

plied by the ratio of manufacturing employees to the sum of manufacturing and full-time agricultural employees. This new measure is designated as PROM."

\section{Estimation Mesurers}

Assuming a linear function, the preceding model can be represented as

(1) $\mathrm{EX}=\mathrm{d}_{0}+\mathrm{d}_{1} \mathrm{~K}+\mathrm{d}_{2} \mathrm{H}+\mathrm{d}_{3} \mathrm{l}+\mathrm{d}_{4}$ PROM $+\mathrm{e}$

where the d's are the parameters to be estimated and $e$ is the disturbance term. The model was estimated using generalized least squares because the residuals using ordinary least squares indicated heteroscedasticity." "The results, which were also reported in Coughlin and Cartwight (1987), are listed under variant \#1 in table $2 .{ }^{12}$ The results indicate that both physical and human capital are positive, statisticaly significant determinants of state manufacturing exports. The remaining endowment variable, labor, is not statisticaly significant.

For present purposes, the positive impact of export promotion expenditures is the key result; however, the statistical significance of this variable hinges on whether a 5 percent or 10 percent significance level is chosen. The point estimate indicates that manufacturing exports, on average will increase by 432 for a one-unit increase in manufacturing export promotion expenditures. Since expont promotion expendilures are measured in thousands of dollars and exports are measured in millions of dollars, an increase in export promotion expenditures of $\$ 1000$ is estimated to increase exports by $\$ 432,000$.

This estimate seems much too large and, in fact. there are reasons to think the estimate is biased

\footnotetext{
"Following Glejser (1969), the weights for the observations are determined by a two-step procedure. First, the residuats from an ordinary least squares regression of equation 1 are generated. Second, the inverses of the weights are generated by a linear uncton using total state employment as the determinant of the absolute value of the residuals from the first step. See Fomby et al. (1984), pp. 180-82, for details.

17Since Washington was uncharacteristic in the sense that the actual value of exports was exceptionally large telative to its predicted value, it was gropped from the estimation.

t3it should be noted that export promotion expenditures likely have important investment aspects. The results of current expont promotion expenditures will not necessarily occur immediately. Consequently, export promotion expenditures in 1980 will affect expors in future periods as well as the current period, and exports in 1980 were likely affected by previous export promotion expenditures. Because of absence of suffic-

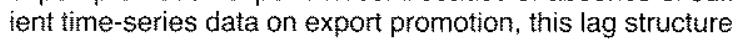
coutd not be estimated.
}

Two other adjustments to total export promotion expenditures were examined; these adjustments did not alter the empirical results. Jotal export promotion expendtures were multiplied by: (1) the percentage of a state's poputation that did not live on farms; and (2) the ratio of manutacturing employees to the sum of manufacturing and total agricutural employees. Total export promotion expendiures were found in Berry and Mussen (1980). The adjustment factors to develop estimates of manufacturing export promotion expenditures were taken from the Statistical Abstract of the United States (farm population tigures) and the Census of Agricuture (agricuturat employment igures). 
Table 2

\section{Export Promotion Variants of 1980 State Export Functions}

\section{Dependent Variable: EX}

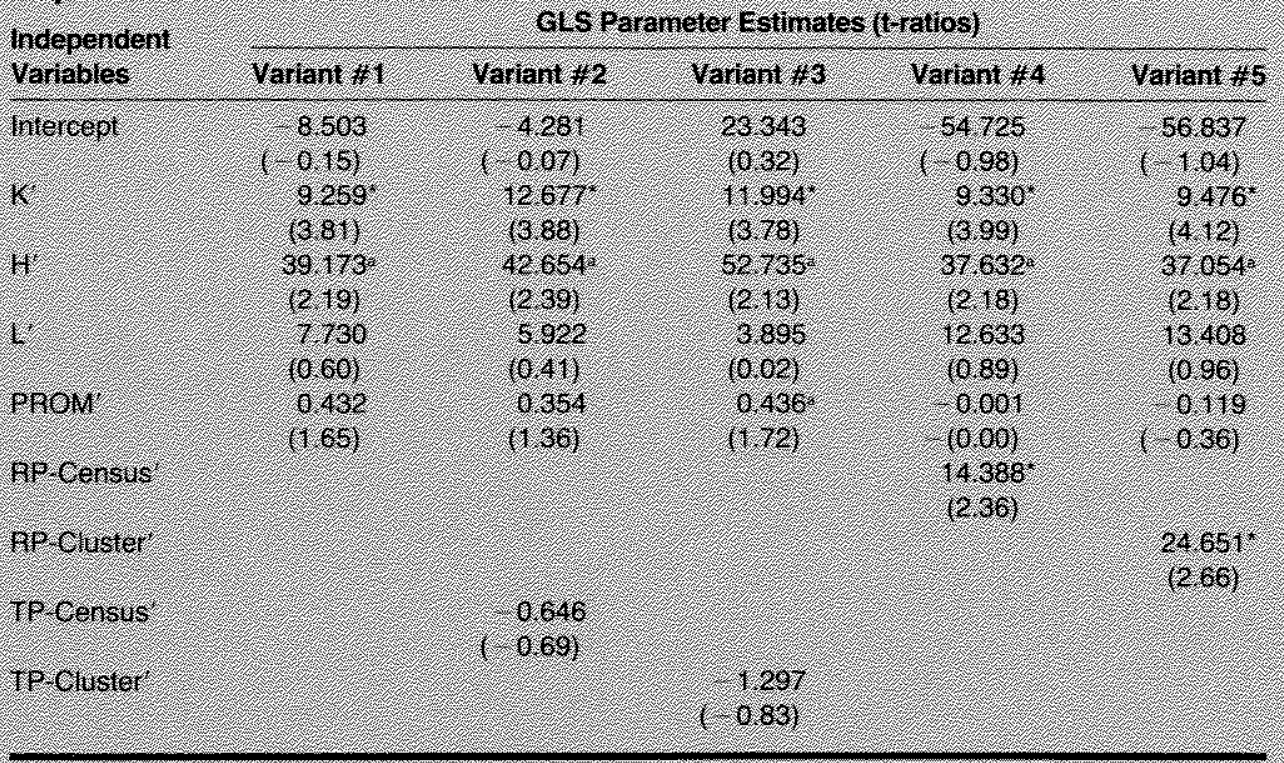

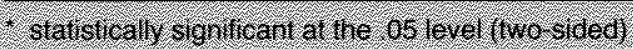

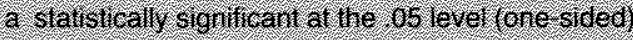

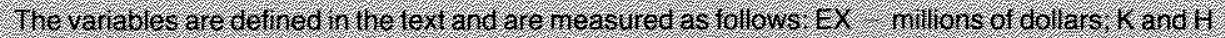

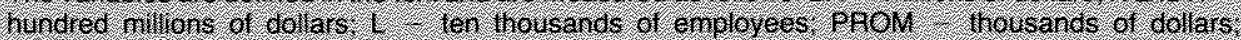

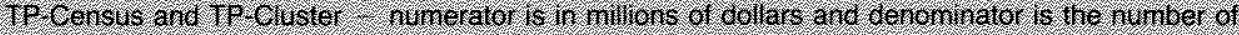

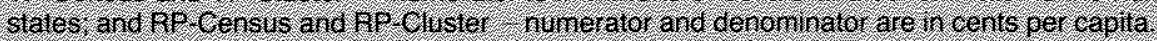

upward. First, as mentioned previously, the reported state budget expenditures on export promotion are likely a lower bound. To the extent these figures are understated, the coefficient estimate will be overstated. For example, if the export promotion expenditures are understated by 50 percent, the coefficient estimate should be halved. Second, the model does not control for either private or other governmental export promotion expenditures. To the extent that these other export promotion expenditures are correlated with state expenditures, the coefficient estimate is biased upward. Finally, due to the lack of data, there is no lag structure in the model. Consequently, while export promotion expenditures and exports are positively related, the point estimate is likely unreliable.

\section{Cross-State Afects}

Attention can now be focused upon whether there are externalities associated with export promotion. If these externalities exist, they could be positive or negative, Export promotion expenditures by other states might increase export demand generally and produce additional exports from the state in question. On the other hand, perhaps a substitution effect exists; increases in export promotion expenditures by one state will reduce the exports of other states. ${ }^{14}$ In this case, a state may be forced into promotional efforts as an act of self-defense.

Ascertaining the existence of externalities is neither easy nor straightforward. The preceding

\footnotetext{
${ }^{14}$ Even though a siate's expots may be aftected adversely by the export promotion experditures of competitive states, the state may not necessarily incur short-run employment losses because the export demand reduction could be offset by increased domestic demand.
} 
paragraph focuses on the notion of competitive export goods; however, the dependent variable is total state exports. Given this aggregation, the idea of competitive exports must be transformed into competitive states. For example, it is difficult to envision how export promotion by South Carolina would affect Alaska; it is not difficult, however, to envision how export ptomotion by South Carolina would affect North Carolina. The notion of competitive states was developed in two ways. First, states were viewed as competitive if they belong to the same census region..$^{15}$ Since geography is a key feature of this categorization, an attempt to classify states on the basis of certain economic characteristics was made. The results reported in variant \#1 in table 2 reflect the fact that states have different sounces of comparative advantage. Competitive states should be those states whose sources of comparative advantage that is, resource endowments) are similar. A cluster analysis was performed that grouped states into seven clusters based on their ratios of physical capital to labor and human captal to labot: ${ }^{\text {:6 }}$

After the states were grouped, the next step was to construct reasonable variables to test for externalities. There are numerous reasonable candidates. The difficulty arises because of the necessity of scaling the promotional expenditures of competitive states, For example, assume two groups of states, one containing five states and the other three states. The goal of the regression analysis is to indicate the impact upon a member of a group when promotional expenditures by another mem- ber (or members) increase. It seems reasonable that the larger the group the smaller the impact on any individual member of increased expenditures by another member. The effect is lessened because it is spread over more states. A straightforward approach is to divide the total promotional expenditures of competitors by the number of competitors. These variables are designated as TPCensus and TP-Cluster. The existence of a positive impact of a region's export promotional expenditures will be revealed by a positive sign for the TP variables, while a negative impact will be revealed by a negative sign.

Another approach to test for externalities is to use a state's spending on export promotion relative to the spending of its competitors. Scaling the promotional expenditures of a state relative to its competitors is accomplished by dividing both expenditures by their respective populations. ${ }^{57}$ These variables are designated as RP-Census and RP-Cluster. If a region's per capita export promotion expenditures increase, ceteris paribus, then the ratio of state to region per capita export promotion expenditures will decline. Consequently, the existence of a positive impact of a regions's export promotion expenditures will be revealed by a negative sign for the $k$ variables, while a negam tive impact will be revealed by a positive sign.

Variants \#2 and \#3 in table 2 highlight the effect of adding TP-Census and TP-Cluster to the basic model, while variants \#4 and \#5 highlight the effect of adding RP-Census and RP-Cluster. The
:5The nine census regions are as follows: New England Connecticut, Maine, Massachusetts, New Hampshire, Rhode Island and Vermont; Middle Atlantic New Jersey, New York and Pennsylvania; Eas Noth Central - Minois, Indiana, Michigan, Ohio and Wisconsin; West North Central - lowa, Kansas, Minnesota, Missouri, Nebraska, North Dakota and South Dakota; South Alantic m- Delaware, Florda, Georgia, Maryland, Noth Carolina, South Carolma, Virginia and West Virginia; East South Central - Alabama, Kentucky Mississippi and Tennessee; West South Central --Arkansas, Louisiana, Oklahoma and Texas; Mountain - Arizona, Colorado, Ldaho, Montana, Nevada, New Mexico, Utah and Wyoming; and Pacitic - Alaska, California, Hawaii, Oregon and Washington.

3The clusters were generated using the CLUSTER procedure in SAS. The purpose of cluster analysis is to group objects such that those in a given cluster tend to be similar to each other in some sense while those in different clusters tert to be dissimilar. In the present case, states with similar ratios of physica capital to tabor and human capital to labor were grouped to gether. The procedure, described on pages 423 and 424 in the SAS User's Guide: Statistics (1982), begins with each observation (i.e., state) as a cluster by itself. Next, the two closest clusters are combined to form a new cluster. This merging continues until only one cluster remains. There are different clustering algorithms with the distinguishing feature being how the difference between two clusters is measured. In Ward's method, which was the specific algorithm used, the distance between two clusters is the sum of squares between the two clusters over all clusters. At each step, the within-cluster sum of squares is minimized over an the possibilities obtainabte by merging two clusters from the previous step. This method was used to reduce the original 49 clusters untit there were the following seven groups: (t) Calitorna, New York, Connecticu and New Jersey; (2) Arizona, Missouri, Oklahoma, Utah, Wisconsin, Massachusetis, Minnesota, Colorado, Oregon, Pensyvania, Maryland and Nevada; (3) Indiana, Delaware, Ohio, Illinois, Washington and Michigan; (4) Alabama, Idaho, North Dakota, Hawaii, Kentucky, lowa and Now Mexico; (5) Florida, Tennessee, Georgia, Kansas, Vizginia, New Hampshire and Rhode Island; (6) Arkansas, Mane, South Carolina, Mississippi, Nebraska, North Caroina, Vermont and Soun Dakota; and (7) Texas, West Virginia, Wyoming, Alaska, Louisiana and Montana.

${ }^{17}$ The ratio of state to region per capita export promotion expenditures was sefected rather than the ratio of region to slate because of Utah's zero value for export promotion. This complicates the interpretation of the variable, but was unavoidable. 
only unqualified conclusion is that there is no substantial impact on the statistical results for the factor endowment variables. The remaining conclusions must be qualified.

The results, while similar for both groupings of competitive states, are sensitive to which method is used to control for externalities. The results for each variant indicate that increases in promotional expenditures by competitors, ceteris paribus, are associated with a reduction in a state's exports; however, the results are not strong. Total promotional expenditures divided by the number of competitors in variants \#2 and \#3 is not a statistically significant determinant of state exports, while state per capita promotional expenditures divided by competitors' per capita promotional expenditures in variants \#4 and \#5 is a statistically significant determinant. In addition, the impact of adding the variable to control for externatities has different effects on the export promotion variable (PROM). The t-ratios are roughly similar in variants \#2 and \#3 compared to variant \#1. In fact, in variant \#3 PROM is statistically significant. On the other hand, in variants \#4 and \#5 the $\mathrm{t}$ ratio for PROM is virtually zero.

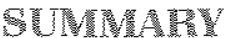

The results, which should be viewed as tentative because of the acknowledged data limitation, highlight the effects of export promotion expenditures. Using two groupings of competitive states, statistical evidence was found that exports from a state are affected adversely by the promotional expenditures of other states; however, another reasonable variable designed to capture this effect was statistically insignificant. Thus, definitive conclusions about the effects of export promotion expenditures are not possible. Nonetheless, one suggestion does emerge. In light of the large increases in expenditures and the increasing use of financial incentives to promote state exports, the competitive and efficiency aspects of export promotion expenditures and programs deserve additional scrutiny. ${ }^{18}$ At this point, the lack of timeseries data is the major obstacle.

\section{MEFTRECES}

Albaum, Gerald. State Government Promotion of Intemational Business (University of Arizona, Division of Economic and Business Research, 1968).
Aw, Bee-Yan. "The Interpretation of Cross-Section Regression Tests of the Heckscher-Ohlin Theorem With Many Goods and Factors," Joumal of International Economics (February 1983), pp. 163-67.

Baldwin, Robert E. "Determinants of the Commodity Structure of U.S. Trade," American Economic Review (March 1971), pp. $126-46$.

Barovick, Richard. "State Governments Broaden Range of Export Expansion Activities," Business America (October 1, 1984), pp. 16-18.

Berry, Willard M., and William A. Mussen. "Part I - A Report," in Export Develooment and Foreign Investment: The Role of the States and its Linkage to Federal Action (Committee on International Trade and Foreign Relations, National Governors' Association, 1980).

Bowen, Harry P. "Changes in the International Distribution of Resources and Their Impact on U.S. Comparative Advaritage," Review of Economics and Statistics (August 1983), pp. 402-14.

Boyd, John $\mathrm{H}$. "Eximbank Lending: A Federal Program That Costs Too Much," Federal Reserve Bank of Minneapolis Quarterly Review (Winter 1982), pp. 1-17.

Branson, William H., and Helen B. Junz. "Trends in U.S. Trade and Comparative Advantage," Brookings Papers on Economic Activity (1971:2), pp. 285-345.

Browne, Lynn E., P. Mieszkowski, and R.F. Syron. "Regional Investment Patterns," New England Economic Review (July/ August 1980), pp. 5-23.

Coughlin, Cletus C., and Philtip A. Cartwright. "An Examination of State Foreign Export Promotion and Manufacturing Exports," Journal of Regional Science (August 1987), pp. 43949 .

Coughilin, Cletus C., and Oliver Fabel. "State Factor Endowments and Exports: An Alternative to Cross-Industry Studies;" Review of Economics and Statistics, forhcoming

Fomby, Thomas B., R. Carter Hill, and Staniey R. Johnson. Advanced Econometric Methods (Springer-Verlag, 1984).

Glejser, H. "A New Test for Heteroscedasticity," Journal of the American Statistical Association (1969), pp. 316-23.

Hutbauer, Gary C. "The Impact of National Characteristics and Technology on the Commodity Composition of Trade in Manufactured Goods," in Raymond Vernon, ed, The Technology Factor in international Trade (National Bureau of Economic Research, 1970), pp. 145-231.

Krugman, Paul R., and Maurice Obsteld. International Economics: Theory and Policy (Scott, Foresman and Company, 1988).

Leamer, Edward E., and Harry P. Bowen, " ${ }^{\text {"Cross-Section }}$ Tests of the Heckscher-Ohlin Theorem: Comment," American Economic Review (Decerbber 1981), pp. 1040-43.

Leontief, Wassily W. "Domestic Production and Foreign Trade; the American Capital Position Re-examined," Economia Internazionale (February 1954), pp. 3-32.

National Association of State Development Agencies. State Export Program Database (NASDA, 1986).

Ouida, Herbert. "XPORT: Port Authority ETC Simplifies and Expands Export Operations," Business America (March 19 1984), pp. 8-12.

\footnotetext{
${ }^{18}$ in a recent cost-benefit analysis of the Export-lmport Bank of the United States, Boyd (1982) concluded that for 1976-80 the annual costs exceeded the benefits by an average of $\$ 200$
} miltion. 
Prestowitz, Clyde V., Jr. Trading Places: How We Allowed Japan to Take the Lead (Basic Books, Inc., 1988).

Sailors, J.W., R.W. Thomas, and S. Luciani. "Sources of Comparative Advantage of the United States," Economia Internazionale (May -August 1977), pp. 282-94.

SAS User's Guide: Statistics, 1982 Edition (SAS Institute, 1982).

Stern, Robert M., and Keith E. Maskus. "Determinants of the Structure of U.S. Foreign Trade, 1958-76, , Journal of Intemational Economics (May 1981), pp. 207-24.
U.S. Department of Agriculture. 1982 Census of Agriculture -Geographic Area Series - Volume 1, Pant 51 (GPO, 1984).

U.S. Department of Commerce, Bureau of the Census. Annual Survey of Manufactures (GPO, various years).

1980 Census of Population - Volume 1, Character. istics of the Population -.. Part 1, United States Summary (GPO, December 1983).

. Statistical Abstract of the United States (GPO, various years). 